Акушерство та гінекологія

УДК 618.1-0.06.5526-08

®О. І. Хлібовська, А. В. Бойчук, В. Г. Дживак

ДВНЗ « Тернопільський державний медичний університет імені І. Я. Горбачевського МO3 України»

\title{
АНАЛІЗ РЕЗУЛЬТАТІВ КОМПЛЕКСНОГО ЛІКУВАННЯ ЕНДОМЕТРІОЗУ ЖІНОЧИХ СТАТЕВИХ ОРГАНІВ
}

АНАЛІЗ РЕЗУЛЬТАТІВ КОМПЛЕКСНОГО ЛІКУВАННЯ ЕНДОМЕТРІОЗУ ЖІНОЧИХ СТАТЕВИХ ОРГАНІВ. НаМИ провеДеНО аналіз результатів комплексного лікування 86 пацієнток з зовнішнім генітальним ендометріозом. Контрольну групу склали 25 здорових жінок. Першим етапом лікування було лапароскопічне органозберігаюче втручання 3 наступним призначенням 3 першого менструального циклу гормонотерапії оргаметрилом у безперервному режимі в дозі 5-7,5 мг. Хірургічне лікування ендометріозу полягало у видаленні видимих ділянок ендометріозу і відновленні нормальних анатомічних взаємовідносин у порожнині таза. 3 метою діагностики в доопераційному періоді та з метою ранньої діагностики рецидивування ендометріозу проводили в динаміці гінекологічне обстеження, УзД, визначення СА 125. Запропонована терапія дозволила зменшити симптоми ендометріозу та відновити репродуктивну функцію жінки.

АНАЛИЗ РЕЗУЛЬТАТОВ КОМПЛЕКСНОГО ЛЕЧЕНИЯ ЭНДОМЕТРИОЗА ЖЕНСКИХ ПОЛОВЫХ ОРГАНОВ. НаМИ проведен анализ результатов комплексной терапии 86 больных 3 внешним генитальным эндометриозом. Контрольная группа - 25 здоровых женщин. На первом этапе проводилась органосохраняющая лапароскопическая операция с назначением в дальнейшем гормонотерапии оргаметрилом в непрерывном режиме в дозе 5-7,5 мг. При хирургическом лечении эндометриоза проводили удаление видимых участков эндометриоза и восстановление нормальных анатомических взаимоотношений в полости таза. Для диагностики в дооперационном периоде и с целью ранней диагностики рецидива эндометриоза проводили гинекологическое обследование, УЗД, определение уровня СА 125. Предложенная терапия уменьшила симптомы эндометриоза, но и позволила возобновить фертильность.

ANALYSIS OF RESULTS OF COMPLEX TREATMENT OF ENDOMETRIOZIS OF FEMALE GENITAL ORGANS. We analyzed the results of treatment of 86 patients with external genital endometriosis. The control group consisted of 25 healthy women. The first step in treatment is laparoscopic organ interference with the subsequent appointment of the first menstrual cycle hormone therapy orhametryl in continuous mode at a dose of $5-7,5 \mathrm{mg}$. Surgical treatment of endometriosis aims to remove visible areas of endometriosis and restore anatomy by division of adhesions.In order to diagnosis in preoperative period and for early diagnosis of recurrence of endometriosis was performed in the dynamics gynecological examination, ultrasound, determination SA125. The proposed therapy has reduced the symptoms of endometriosis and restore reproductive function of women.

Ключові слова: ендометріоз, больовий синдром, комплексна терапія.

Ключевые слова: эндометриоз, болевой синдром, комплексная терапия.

Key words: endometriosis, pain syndrome, complex therapy, hormones.

ВСТУП. Генітальний ендометріоз - одна 3 найбільш актуальних проблем гінекології. Це зумовлено тим, що частота ендометріозу не має тенденції до зниження, а навпаки, продовжує зростати. Так, у структурі гінекологічної захворюваності ендометріоз займає третє місце після запальних захворювань жіночих статевих органів і міом матки $[1,2]$. Багаторічні тривалі дослідження залишили не до кінця вивченим патогенез захворювання, який представлений численними теоріями [1-3]. Важливість проблеми зумовлена тим, що ендометріоз призводить до порушення якості життя жінок. Разом з тим, клінічна картина не завжди відповідає тяжкості захворювання [1- 3, 11]. Наукові розробки останніх років вказують, що в жінок, хворих на ендометріоз, частота настання вагітності значно нижча, ніжу здорових [1-3]. Встановлено, що в популяції у фертильних жінок під час лапароскопії ендометріоз виявляють у 10-15 \%, тоді як у пацієнток з безпліддям - у 15-80\% $[2-4,6,8,9]$. Вченими різних країн постійно проводиться пошук причин та шляхів розвитку цього захворювання 3 метою розробки оптимальних методів лікування [1-3, 12]. Питання ранньої діагностики, пошук нових методів лікування ендометріозу та підвищення ефективності терапії, а особливо в поєднанні 3 непліддям потребують подальшого вивчення [1-4]. Асоціація між ендометріозом і неплідністю добре відома, та механізми порушення фертильності при даній патології остаточно не вивчені (Marcus S. F., 2001). Тому у гінекологічній практиці на сучасному етапі актуальною $€$ розробка алгоритму лікування та реабілітації репродуктивної функції хворих на генітальний ендометріоз, що $\mathrm{i}$ було підставою до проведення наукових досліджень у даному напрямку.

Мета роботи - вивчення ефективності комплексного лікування зовнішнього генітального ендометріозу у жінок. 


\section{Акушерство та гінекологія}

МАТЕРІАЛИ ТА МЕТОДИ. Під нашим спостереженням перебували 86 пацієнток, які лікувались 3 приводу зовнішнього генітального ендометріозу. Контрольну групу склали 25 здорових жінок. Тривалість захворювання становила $(7,6 \pm 0,9)$ року. Вік хворих коливався від 23 до 43 років. Первинне непліддя було у 71,8 \%, вторинне - у 28,2 \%.

Проводили аналіз анамнестичних даних, клініколабораторне обстеження, гінекологічне дослідження, УЗД, визначали рівень СА 125.

Основні симптоми ендометріозу: больовий синдром, диспареунія, порушення функції суміжних органів (дизурія), психоневрологічні розлади, порушення репродуктивної функції (непліддя та невиношування).

УЗД проводили до оперативного втручання, в післяопераційному періоді та для динамічного спостереження при призначенні гормональної терапії.

Нами розроблена та впроваджена в практику комплексна терапія ендометріозу. На першому етапі проводили оперативне втручання. Лапароскопію виконували 3 використанням ендоскопічної апаратури 3 комплектом інструментарію за загальноприйнятою методикою. При оглядовій лапароскопії виявляли величини ендометріоїдних гетеротопій, їх кількість, зрілість (за кольором і формою), наявність ендометріоїдних кіст та злукового процесу. Оцінка стадії захворювання проводилася в балах. За ступенем розповсюдження процесу хворих поділили таким чином: । стадія (1-5 балів) спостерігалась у 46 жінок, ІІ (615 балів)-30, III (16-40 балів) - 6, IV (більше 40 балів) - 4 (за системою r-AFS). При підході до вибору обсягу втручання дотримувалися принципів щадної хірургії, що $є$ важливим для пацієнток репродуктивного віку, зацікавлениху збереженні або відновленні дітородної функції. Хірургічне лікування ендометріозу було направлене на максимальне видалення ендометріоїдних гетеротопій - кіст яєчників, імплантатів на очеревині, крижово-маткових зв'язках та в інших локалізаціях і відновлення нормальних анатомічних взаємовідносин у порожнині таза.

Для гістологічного дослідження за загальноприйнятою методикою забирали частки ураженого або підозрілого на ураження ендометріозом перитонеума та капсулу кісти. В післяопераційному періоді пацієнткам з ендометріозом призначали гормонотерапію. Курс лікування розпочинали з першого менструального циклу після операції. Тривалість лікування склала 3-6-9 місяців залежно від ступеня поширення та тяжкості процесу.
Препаратом вибору був Оргаметрил (вміст лінестролу 5 мг) (табл. 1). Лінестренол має виражений прогестагенний ефект на ендометрій. Тривале приймання препарату призводить до пригнічення овуляції та менструації. При внутрішньому застосуванні лінестренол швидко всмоктується у шлунково-кишковий тракт і підлягає наступному перетворенню в печінці на фармакологічно активний норетистерон, який і чинить свою біологічну дію. Максимальний рівень норетистерону в плазмі крові відзначається вже через 2-4 год після внутрішнього прийому лінестренолу. Лінестренол і його метаболіти виводяться з організму головним чином із сечею, менше з калом. Після лапароскопічного лікування з першого дня менструального циклу пацієнтки отримували оргаметрил у дозі 5 мг у безперервному режимі 3-6-9 місяців. Проводили динамічне спостереження за ефективністю призначеної терапії (УЗД (1 раз в 3 міс.), визначення динаміки рівня онкомаркерів СА 125 в сироватці крові з метою ранньої діагностики рецидивів ендометріозу).

РЕЗУЛЬТАТИ ДОСЛІДЖЕННЯ ТАЇХ ОБГОВОРЕННЯ. Аналіз клініко-анамнестичних даних показав, що основними скаргами у хворих з ендометріозом були: хронічний тазовий біль, який загострювався перед менструацією, - у $56(65,1 \%)$ при ГЕ і у $3(12,0 \%)$ у контрольній групі, диспареунія - у 53 (61,6 \%) і 2 (8,0 \%). Дані симптоми захворювання частіше всього поєднувались в різній комбінації і зустрічались з однаковою частотою у жінок із ЗГЕ при різних ступенях ушкодження. Значний біль діагностований у всіх жінок 3 III ступенем прояву ендометріозу, а незначний і помірний - з I і II ступенем. Первинне непліддя спостерігалося у 71,8 \% обстежених, вторинне непліддя - 28,2 \%. Малі форми ендометріозу при лапароскопії виявлялися у вигляді «зіниць», які піднімалися над поверхнею очеревини і мали червоний, коричневий, чорний або зелений колір (рис. 1).

При лапароскопії враховувалися як розміри гетеротопій ендометріозу, так і ступінь спайкового процесу. 3 усіх випадків ендометріозу, виявленого нами при лапароскопії, у 68 пацієнток $(79,1$ \%) підтверджено раніше поставлений діагноз, а у 20,9 \% діагноз було встановлено вперше. Частіше зустрічався ендометріоз яєчників (43,9\%), ендометріоз маткових труб та малі форми ендометріозу $(23,4 \%)$. Ретроцервікальний ендометріоз виявлено у 14,2 \% пацієнток. у решті випадків мав місце ендометріоз маткових зв'язок та міхурово-маткової очеревини. В 65,0 \% випадків мав місце спайковий процес різного ступеня вираженості.

Таблиця 1. Прогестини при лікуванні ендометріозу

\begin{tabular}{|l|l|c|c|}
\hline \multicolumn{1}{|c|}{ Прогестин } & \multicolumn{1}{|c|}{ Препарати } & Ендометріоз & КОК або ЗГТ \\
\cline { 3 - 4 } & & мг/добу & мг/добу \\
\hline Норетистерону ацетат & Примолют-нор & $10-20$ & $0,5-0,1$ \\
\hline Дієногест & Жанін & 2 & 2 \\
\hline & Клімодієн & 2 & 2 \\
\hline Лінестренол & Оргаметрил & $5-7,5$ & $0,75-2,5$ \\
\hline Дидрогестерон & Дуфастон & $20-40$ & $20-40$ \\
\hline & Фемостон & $20-60$ & $10-20$ \\
\hline МПА & Дивина & $10-50$ & $2,5-5,0$ \\
\hline
\end{tabular}




\section{Акушерство та гінекологія}

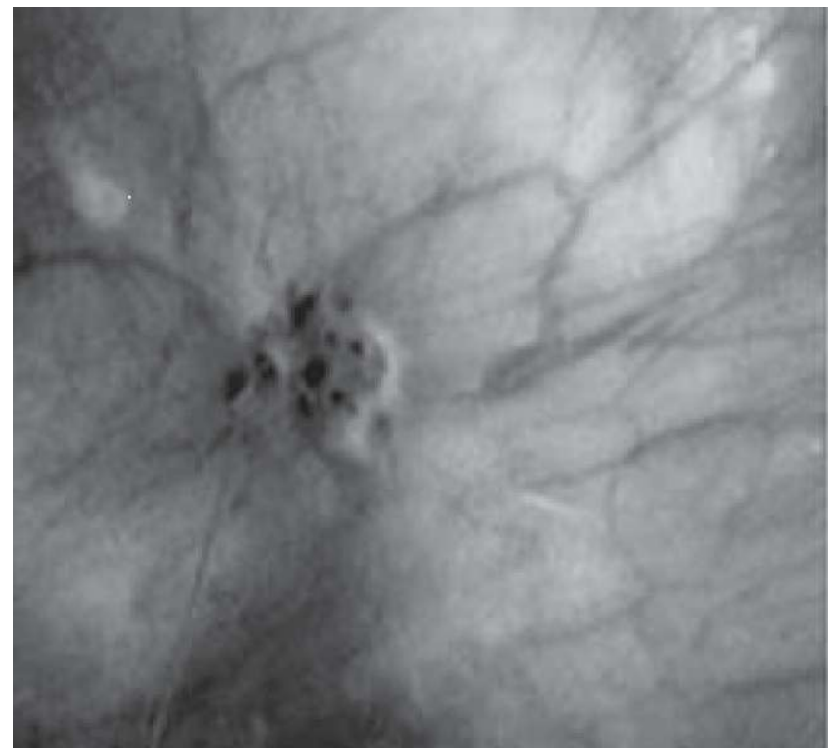

Рис. 1. Малі форми ендометріозу.

Таким чином, лапароскопія дає змогу не тільки виявити ендометріоз, його локалізацію, ступінь розповсюдження, стан матки, маткових труб та яєчників, але й надає можливість виконати ендокоагуляцію ендометріоїдних гетеротопій, взяти біопсію. ЗГЕ був верифікований під час лапароскопії і підтверджений патогістологічними дослідженнями. Обстежених жінок розподіляли на групи після лапароскопічного втручання залежно від важкості і поширеності патологічного процесу. Першу групу склали 69 жінок з I-ІІ ступенем ГЕ, другу - 17 жінок зІІІ-IV ступеня ЗГЕ. Під час лапароскопії проводились хірургічні втручання для видалення ендометріоїдних гетеротопій. У післяопераційному періоді 86 хворим призначали прогестин Лінестренол у добовій дозі 5-10 мг у безперервному режимі 3-6-9 місяців та препарат Гепабене. Концентрація онкомаркера СА 125 у крові в контрольній групі становила $(8,3 \pm 0,2)$ Од/мл, при ендометріозі в 1 групі $(31,2+0,1)$ Од/мл, в 2 групі $(38,2 \pm 0,3)$ Од/мл. Вибір методу і об'єму хірургічного втручання визначався інтраопераційно залежно від локалізації і поширення ендометріоїдного процесу, втягнення кишечника, сечового міхура, а також бажанням зберегти чи відновити репродуктивну функцію. Оперативне видалення ендометріоїдних гетеротопій дає надію на терапевтичний ефект. Проте сучасний підхіддолікування хворих з ендометріозом полягає в комбінації хірургічного методу, направленого на максимальне видалення ендометріоїдних вогнищ, гормональної терапії, що й враховувала розроблена нами методика лікування. Медикаментозна терапія в післяопераційному періоді дає змогу оптимізувати результати хірургічного лікування. Відповідно до механізму дії Оргаметрилу на фоні лікування наступають аменорея і псевдоменопауза. Терміни припинення менструацій варіюють залежно від застосовуваної дози та вихідних характеристик менструального циклу. Больовий синдром, обумовлений ендометріозом, утому числі дисменорея і диспареунія, зменшується або зникає вже до другого місяця лікування у $55-60 \%$ хворих першої групи та 45-55 \% другої групи. При проведенні УЗД через 3 місяці в 1 та 2 групах рецидивів ендометріозу не виявляли. Нормальний менструальний цикл відновлюється приблизно через 45 тижнів після припинення лікування. Частота рецидивування захворювання протягом перших шести місяців після закінчення курсу становила 9,8 \% в першій групі та 19,8 \% в другій групі. Ефективність відновлення генеративної функції у жінок з ендометріозом корелює зі ступенем його розповсюдженості, віком пацієнтки, тривалістю захворювання, ступенем вираженості патологічних анатомічних змін органів малого таза і в середньому становить $45 \%$. Після проведеної комплексної терапії протягом першого півріччя завагітніли $15 \%$ першої групи та 11,7 \% другої групи. Застосування гормонального лікування у хворих з непліддям та ендометріозом у післяопераційному періоді дає змогу: досягти ребаут-ефекту після відміни медикаментозної терапії, який значно збільшує шанси настання вагітності; забезпечити адекватну тривалість так званого періоду тимчасової атрофії імплантатів, необхідного для повноцінного розвитку та імплантації бластоцисти; ліквідувати ендометріоїдні гетеротопії, які залишились після оперативного лікування.

ВИСНОВКИ. Таким чином, комплексна терапія зовнішнього ендометріозу, яка складається 3 лапароскопії в поєднанні з гормонотерапією (ЛІНЕСТРЕНОЛ) у післяопераційному періоді, приводить до зменшення тазового болю, зменшення розмірів та кількості вогнищ ендометріозу, відновлення фертильності, а також попереджує виникнення рецидивів, що, у свою чергу, підвищує якість життя.

ПЕРСПЕКТИВИ ПОДАЛЬШИХ ДОСЛІДЖЕНЬ. Не викликає сумнівів необхідність подальшого вивчення ефективності лапароскопічного втручання та впливу прогестинів на перебіг ендометріозу жіночих статевих органів, що дасть змогу поліпшити лікувальну тактику та наслідки захворювання. 


\section{Акушерство та гінекологія}

\section{СПИСОК ЛІТЕРАТУРИ}

1. Ищенко А. И. Эффективность комбинированного лечения наружного эндометриоза с синдромом хронических тазовых болей с использованием агониста гонадотропин-рилизинг гормона Декапептилдепо / А. И. Ищенко, Е. А. Кудрина, У. А. Абдуллаева // Жіночий лікар. - К., 2006. - № 6 (8). - С. 8-11.

2. Старцева Н. В. Современные аспекты болевого синдрома при эндометриозе / Н. В. Старцева, М. В. Швецов, Ю. В. Беда // Журнал акушерства и женских болезней. - 2002. - T. L1. - С. 94-97.

3. Леонов Б. В. Применение а-ГнРГ при бесплодии / Б. В. Леонов, В.И.Кулаков, В. Ю. Смольникова // Акушерство и гинекология. - 2003. - № 4. - С. 1-4.

4. Адамян Л. В. Эндометриозы : руководство для врачей / Л. В. Адамян, В. И. Кулаков. - М. : Медицина, 1998. - C. 320.

5. Vinatier D. Is endometriosis anendometrial disease? / D. Vinatier, M. Cosson, P. Dufour // Eur. J. Obstet. Gynecol. Reprod. Biol. - 2000. - N 91 (2). - P. 113-125.

6. Endometriosis in reproductive immunology / UlcovaGalovaZ. [etal.] //Am. J. Reprod. Immunol. - 2002. - Vol. 47, N 5. - P. 269-274.
7. Гормональная и иммуноориентированная терапия генитального эндометриоза : пособие для врачей / [В. С. Корсак, М. А. Тарасова, С. А. Сельков и др.]. - СПб. : Издательство Н-Л., 2002. - С. 12.

8. Denny E. Women's experience of endometriosis / E. Denny // J. Adv. Nurs. - 2004. - Vol. 46 (6). P. 641-648.

9. Deutsche Gesellschaft fur Gynakologie und Geburtshilfe (DGGG) // Diagnostik und Therapie der Endometriose. - 2013. - August. - (AWMF Guidelines; Volume 015/045).

10. Fernandez I. Living with endometriosis: The perspective of male partners/ I. Fernandez, C. Reid, S. Dziurawiec // J. Psychosom. Res. - 2006. - Vol. 61(4). - P. 433-438.

11. Hickey M. Endometriosis / M. Hickey, K. Ballard, C. Farquhar // BMJ. - 2014. - Vol. 348. - P. 1752.

12. Ovulation suppression for endometriosis / E. Hughes, J. Brown, J. J. Collins [et al.] // Cochrane Database Sys. Rev. - 2007. - Vol. 3. 